\title{
PETROLOGY OF GABBROIDES AND ISOTOPE SIGNATURE OF SULFIDE MINERALIZATION FROM FEDOROV-PANSKY LAYERED MAFIC INTRUSION, KOLA PENINSULA, RUSSIA
}

\author{
MILOSZ HUBER ${ }^{1}$, STANISLAW HALAS ${ }^{2}$ and ADAM PIESTRZYŃSKI ${ }^{3}$ \\ ${ }^{I}$ Department of Geology and Lithosphere Conservation, Institute of Earth Sciences, Maria Curie-Skłodowska University, \\ Al. Kraśnicka 2CD, 20-718 Lublin, Poland \\ ${ }^{2}$ Mass Spectrometry Laboratory, Institute of Physics, Maria Curie-Skłodowska University, \\ Plac Marii Curie-Skłodowskiej 1, 20-031 Lublin, Poland \\ ${ }^{3}$ Zakład Geologii Złożowej i Górniczej, Wydziat Geologii, Geofizyki i Ochrony środowiska AGH, \\ Al. Mickiewicza 30, 30-059 Kraków, Poland
}

Received 13 January 2009

Accepted 6 May 2009

\begin{abstract}
Samples from Fiodoro-Pansky massif were investigated by polarized light microscopy, EDS electron microscopy and isotope ratio mass spectrometry. We have observed four-stage ore mineralization: (1) magmatic Fe-Ti-oxides, (2) sulfide-ferrous oxide, (3) hydrothermal $\mathrm{Cu}-\mathrm{Ni}$-sulfide with haycokite, talnakhite and galena admixture, (4) tiosulfates formed from pyrrhotite. A few sulfide samples from generations (2) and (4) were investigated isotopically. The second generation is isotopically homogenous with $\delta^{34} \mathrm{~S}$ close to zero, whilst the third generation shows significantly negative $\delta^{34} \mathrm{~S}$ values.
\end{abstract}

Keywords: Fedorov-Pansky massif, layered intrusion, Kola, petrology, ore mineralization, sulfides, stable isotopes.

\section{INTRODUCTION}

In the middle part of Kola Peninsula, northern part of Baltic shield, is located the Imandra-Varzuga belt. This belt is constituted of metamorphised sedimentaryvolcanic rock complex.

Towards North from this belt, Kola rock formation of metamorphised granite-gneiss is located, see Fig. 1. Between these two large formations the Fiodorov-Pansky (F-P) massif is located. The massif consists of layered mafic intrusions of gabbroide rocks. The age of this intrusions ranges from 2501 to $2446 \mathrm{Ma}$ (Latypov and Chistyakova, 2000; Schissel et al., 2002).

The F-P massif belong to the province of the following mafic intrusions: Tornio, Näränkävaara, Penikat, Koillismaa, Lukkulaisvaara which are also distributed in Sveden, Finland and Karelia (Iljina and Hansky, 2005; Sharkov, 2006). Within the whole province, mafic layered intrusions are of similar age and structure. Platinum

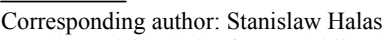
e-mail: stanislaw.halas@umcs.lublin.pl

ISSN 1897-1695 (online), 1733-8387 (print) (C) 2009 GADAM Centre, Institute of Physics, Silesian University of Technology.

All rights reserved. group elements (PGE) often occur in the rocks of these intrusions. The average of PGE content in the F-P massif is $0.1-0.5 \mathrm{ppm}$, with the $\mathrm{Pd} / \mathrm{Pt}$ ratio from 4.2 to 3.3 (Latypov and Chistyakova, 2000).

In this study we analyzed rock samples collected from outcrops and cores of boreholes located in the F-P massif.

\section{METHODS}

Rock samples were analyzed on a HITACHI S-4700 with FESEM (Field Emission Scanning Electron Microscopy) electron microscope equipped with energy dispersion spectroscope (EDS) following by petrography investigation in transmitted and reflected light. Selected mineral samples of chalcopyrite and pyrite were analyzed by means of mass spectrometry for sulfur isotope composition.

The EDS analyses were performed on Field Emission Electron Scanning Microscopy in the Institute of Geology at the Jagiellonian University, Krakow. Petrographic analyses were conducted in the Institute of Earth Sciences and in the Faculty of Geology, Geophysics and Environmental Protection at the Mining Academy (AGH) in 


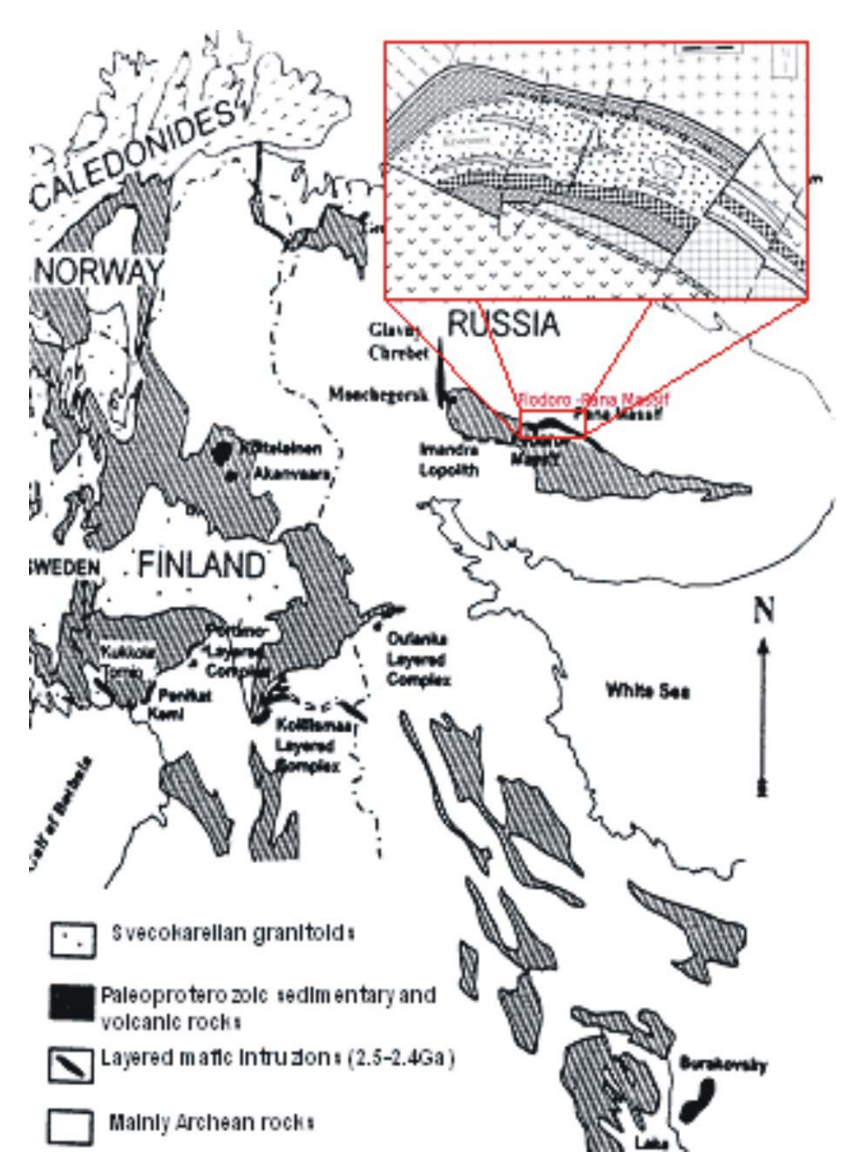

Fig. 1. Geological map showing position of intrusive rocks (after Mitrofanov et al. 2005, Latypov and Chistyakova, 2000).

Krakow, whilst the isotope analyses were performed in the Institute of Physics at Marie Curie-Skłodowska University (UMCS), Lublin. The isotope analysis was done on dual inlet and triple collector mass spectrometer using $\mathrm{SO}_{2}$ prepared off line by $\mathrm{CuO}$ oxidation. The precision of $\delta^{34} \mathrm{~S}$ values was $0.05 \%$, the results were normalized to the VCDT scale by analysis $\mathrm{SO}_{2}$ gas prepared from the international standard IAEA-S-1.

\section{RESULTS AND DISCUSSION}

The F-P massif mainly consists of layered gabbronorites, with contain olivine-norite and olivine plagiopyroxene horizons with $\mathrm{Cu}, \mathrm{Ni}$-sulfide mineralisation (Mitrofanov et al,. 2005, Iljina and Hansky, 2005). The F-P massif consists of several zones (Shissel et al., 2005), namely: marginal mafic schists (bottom zone), taxitic gabbronorite (bpCa), norite (bCpa, pbC), main gabbronorite $(\mathrm{paCb})$, lower layered horizon $(\mathrm{bC}, \mathrm{pC}, \mathrm{pbaC})$, gabbro zone ( $\mathrm{paCb}, \mathrm{pbaC}$ ), upper layered horizon (po$\mathrm{Cab})$, upper gabbro zone (paCb).

These rocks are composed of partly sericitized plagioclase, mainly bytovnite (Table 1). Pyroxenes occur between plagioclase crystals forming offite type of structure. In some samples, oligoclase and garnet of grossular compositon $(83.93 \%$ grs, $16.07 \%$ alm) have been detected. Within pyrrhotitic type of gabbro xenolites of ultramaffic rocks, e.g. norite composed of cpx, opx, olivine (Fig. 2b), have also been described (Latypov and
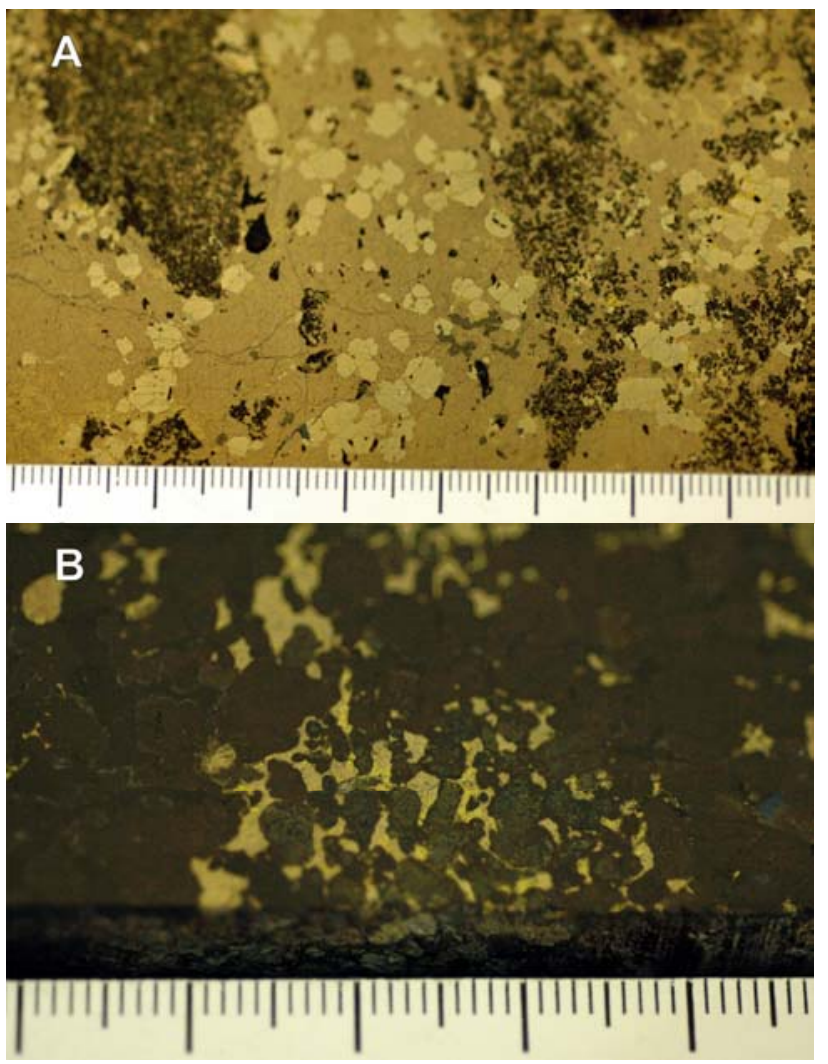

Fig. 2. (a) Macrophotographs of massive sulfate ores (pyrite + pyrrhotite), (b) gabbro containing some pyrrhotite.

Chistyakova, 2000). Massive sulfate ore shoots composed of pyrite, chalcopyrite and pentlandite occurred in the layer complex (Fig. 2a).

Ore mineralization was developed during multistage processes. The first stage is related to gabbroidal type of host rocks. This stage is characterized by presence of magnetite, titanomagnetite and ilmenite (Fig. 3a). The next stage is characterized by sulphide association, that seems to be younger in comparison to oxide one, because sulfides cut oxides. Sulfides are represented by pentlandite, pyrrhotite, pyrite, chalcopyrite, haycockite, talnakhite and minor galena. Sulfides formed dispersions, veinlets and locally massive nest type structures. Usually formed intergrowth between themselves. Chalcopyrite group of sulfides is younger than Fe-Ni- association. Pyrrhotite is locally oxidized to thiosulfates. (Fig. 3e).

The isotopic composition of the investigated sulfides expressed in terms of delta values is shown in Table 2. It should be noted that, with one exception, the results are close to zero in the VCDT scale, i.e. the isotopic composition is like in meteorites and primary Earth crust formed before $2.2 \mathrm{Ga}$ (Hattori et al., 1983). The only exception is the sample 490.183_8-1 with more negative value. However, this sulfide was formed later than the remain-

Table 1. Chemical composition of plagioclase based on EDS measurements.

\begin{tabular}{llccc}
\hline Sample & 1MP & 1MP & 4MP & 5MP \\
\hline$\% \mathrm{An}$ & 82.1 & 89.16 & 80.44 & 77.75 \\
\hline
\end{tabular}




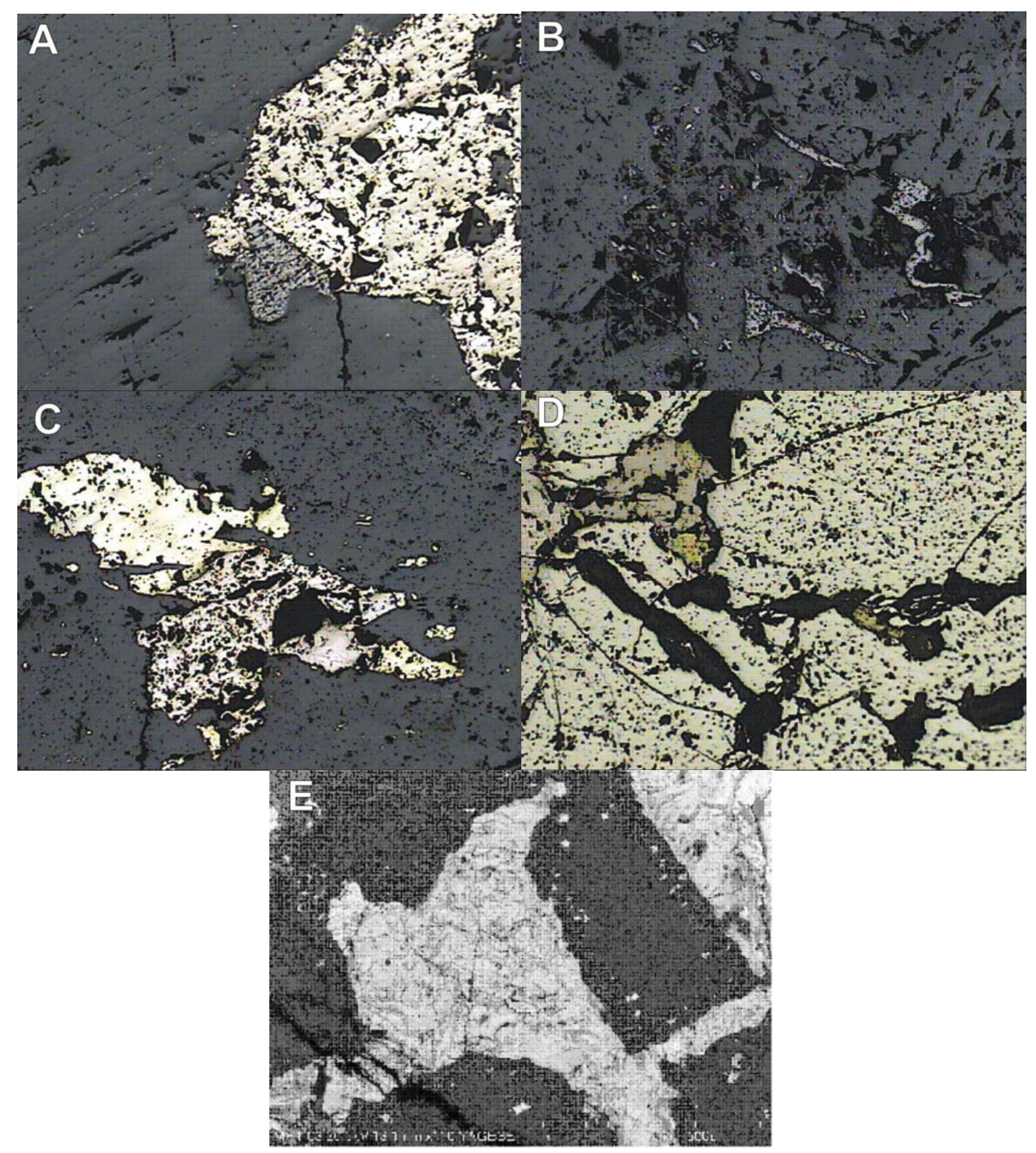

Fig. 3. Microphotographs (in reflected light, $1 \mathrm{~N}$ ) of ore minerals: (a) pentlandite with magnetite, (b) vainlets structure of magnetite, (c) pentlandite and chalcopyrite, (d) chalkopyrite, pyrite and pyrrhotite in massive ore, (e) sulfides with oxidized to thiosulpates zone (BSE microphotographs).

ing sulfides, most likely prior to $2.2 \mathrm{Ga}$ ago, when sulfur was already fractionated isotopically by oxidativereductive reactions (Monster et al., 1983, Hattori et al., 1983).

A multistage character of ore mineralization is a result of genesis of the host rocks. The oldest generation composed of Ti-Fe-oxides is related to the stage of a cumulate formation. Probably pentlandite can be included to end of this stage. The next stage of deposit formation, composed of $\mathrm{Cu}-\mathrm{Fe}-\mathrm{Ni}$ sulfides, is probably related to the hydro- thermal activity during interaction of a primitive magma injected to the chamber with the magma which underwent differentiation. The same source of sulfur is confirmed by the similar sulfur isotope composition. Small differences in $\delta^{34} \mathrm{~S}$ may result from differentiation during fluid transport. Some sulfides from hydrothermal association are partly oxidized. As a result of such a process, thiosulfate phases have been formed. This process is developed mostly on pyrrhotite. 
Table 2. $\delta^{54} S$ isotopes of chalcopyrite and pyrite.

\begin{tabular}{|c|c|c|c|c|c|}
\hline Sample & 05MP & 06MP & 490.183_8-1 & 350/64_2 & $55759 / 5690 \mathrm{a}$ \\
\hline$\delta^{34} S_{V C D T}(\%)$ & 0.16 & 0.28 & -1.98 & 0.60 & -0.30 \\
\hline
\end{tabular}

The sulfur isotopic composition of the investigated sulfides points on their origin from the magma injected before $2.2 \mathrm{Ga}$ and also thereafter (sample 490.183_8-1). Hence, we may conclude from our isotope data that the magmatic process in the F-P massif was multistage. In contrast to our results, the sulfur isotopic composition published by Schissel et al. (2002) are significantly scattered, most likely due to lower precision of isotope analysis $(0.3 \%)$. Both the deposit and host rocks strata have been affected by regional type of metamorphism of the green facies, which is confirmed by presence of albitechlorite association and, grossularite.

\section{CONCLUSION}

Among the four mineralogical stages on the basis of the stable isotopic analysis we have demonstrated the two-stage formation of sulfide mineralization in gabbroide rocks in F-P massif. The first stage (mineralogical stage 2) is magmatic, whilst the second (mineralogical stage 3) is hydrothermal. The older sulfide generation is isotopically correlated with the age of host rock.

\section{ACKNOWLEDGEMENTS}

This study was supported by UMCS Rector in framework of grant No. BW-01-1199-05-08.

\section{REFERENCES}

Hattori K, Krouse HR and Campbell FA, 1983. The start of sulfur oxidation in continental environments: about $2,2 \times 10^{9}$ y.a. Science 221: 549-551, DOI 10.1126/science.221.4610.549.

Iljina M and Hansky E, 2005. Layered mafic intrusions of the TotnioNäränkävaarabelt, In: M. Lehtien, P A Nurmi, O T Rämö, Eds., Precambrian Geology of Finland - Key of the Evolution of the Fennoscandian Shield. Amsterdam, B.V. Amsterdam: 101-138.

Latypov P M and Chistyakova S J, 2000. Mechanizm dypherencyacji rassloyennovo intruziva Zapadno-Panskich Tundr (Mechanism of differentiation in laminated intrusion of West-Pansky Tundra). Editorial RAN, Apatites: 365 pp (in Russian).

Mitrofanov FP, Korchagin AU, Dudkin KO and Rundkvist TV, 2005. Fedorov-Pansky layered mafic intrusion (Kola peninsula, Russia): approaches, methods and criteria for prospecting PGES, Exploration for Platinium-group elements deposits. Chapter 15, Mineralogical Asociation of Canada, University of Toronto: 343-358.

Monster JP, Appel WU, Thode HG, Schidlowski M, Carmichael CM and Brigdwater D, 1979. Sulfur isotope studies in early Archean sediments from Isua, West Greenland: implications for the antiquity of bacterial sulfate reduction. Geochimica et Cosmochimica Acta 43(3): 405-413, DOI 10.1016/0016-7037(79)90205-9.

Sharkov EW, 2006. Formation of Layered Intrusions and Related Ore Mineralization. Moscow, Nauchnyi Mir: 366pp (in Russian).

Schissel D, Tsvetkov AA, Mitrofanov FP and Korchagin U, 2002. Basal Platinum-Group Element Mineralization in the Federov-Pansky Layered Mafic Intrusion, Kola Peninsula, Russia. Economic Geology 97(8): 1657-1677, DOI 10.2113/97.8.1657. 